\title{
The comparative study in reading comprehension achievement on students with visual, auditory, and kinesthetic learning styles
}

\author{
Risa Destriani ${ }^{1}$, Bambang Setiyadi ${ }^{2}$, Huzairin ${ }^{3}$ \\ Universitas Lampung, Jl. Prof. Dr. Sumantri Brojonegoro, Rajabasa, Bandar Lampung \\ Corespondence $^{1}$ : rdestriani23@gmail.com
}

\begin{abstract}
Reading has an influential role in language achievement where each student has their own preferred way to guide them which is called learning styles. The researcher interested in conducting the comparative study because students' learning styles i.e., visual, auditory, and kinesthetic have dissimilar attainment in reading comprehension. The objectives of this research were to determine i) the significant difference in students' reading comprehension achievement among students with visual, auditory, and kinesthetic learning styles and ii) the highest and lowest reading aspect of each VAK student's achievement. The approach of this research was quantitative. The sample of this research was 30 students in X IPA 6 chosen by purposive sampling method. Questionnaires and reading test were used to collect the data. The data were analyzed by using One Way Anova and MANOVA in SPSS 17.0 for Windows. The result showed there was a significant difference in students' reading comprehension achievement based on their learning style since the f-value was 1.287 with the alpha 0.07 . In addition, the result of the VAK students' achievement showed the highest aspect of visual students was determining vocabulary, while the highest aspect of auditory and kinesthetic students was determining reference. The lowest aspect of visual and auditory students was finding main idea while the lowest aspect of kinesthetic students was making inference.
\end{abstract}

Keywords: reading comprehension, reading achievement, reading aspects, visual, auditory, kinesthetic

\section{INTRODUCTION}

According to Joycey (2006:2), reading is an enthusiastic skill, where the reader goes into the text and enlarges on it. Reading has an influential role because of many processes and important things that happen in learning language skills. As Alharbi (2015) as cited in Anderson et al., (1985) said that the ability to read and comprehend efficiently is necessary to deliver opinions for success in the academic arena. This skill badly influences English achievement. According to Nuttal (1982), there are five aspects of reading comprehension i.e. identifying main ideas, finding specific information, determining reference, making inference, and understanding vocabulary.

The majority of learners confront many difficulties while reading such as facing the linguistics analysis of text, making inferences from the text, integrating ideas, and monitoring their own comprehension (Oakhill, 1993). However, Ellis (1985) argued that language learners have differences of learning style which refers to an individual's habitual and preferred way of absorbing, processing and retaining new information and skills particularly in reading comprehension. 
Dunn and Dunn's (1993) have classified the learning styles of the students based on their preferences in learning which called The VAK (Visual, Auditory, and Kinesthetic) learning style. As there are some types of learning styles, there are different reading achievements among the students. Thus, the aim of this research was to find out the highest and lowest students' reading achievement based on each of the VAK students. The researcher interested in conducting the comparative study because students' learning styles i.e., visual, auditory, and kinesthetic definitely have the dissimilar attainment in reading comprehension. Those would show the highest and lowest achievement of the students particularly in reading aspects.

Numerous studies have recently been undertaken with VAK (Visual, Auditory, and Kinesthetic) learning style in reading comprehension. Bidabadi \& Yamat (2010) did a study on learning style preferences. The results demonstrated that there was no statistically significant difference between the mean scores of students' learning style preferences. Mulalic, Mohd Shah, \& Ahmad (2009) revealed that the students' preferred learning style was kinesthetic. They expressed minor preference for visual and auditory. Bricheno \& Younger (2004) suggested that contrary to expectations derived from assertions within some of the literature, there was no significant relationship between gender and preferred learning styles.

To clearly support this research, here are some previous studies regarding this research The Comparative Analysis of Students' Learning Style on Their Reading Skill by Fithrotunnisa (2015). The study done by Fithrotunnisa was aimed at knowing the difference of the students' learning style, especially in terms of VAK (Visual, Auditory, Kinesthetic) in their English learning skill. In short, the result of the study shows that the best learning style in reading is visual style. Almost all of the studies found that VAK learning styles had a statistically significant effect on reading comprehension.

\section{METHODS ${ }^{1)}$}

\section{Participants}

The population of this research was the first grade of SMAN 3 Bandar Lampung. It consisted of six science classes and five social classes. Purposive sampling method was used and it selected $\mathrm{X}$ science 6 as the subject with 30 students.

\section{Instruments}

In order to collect the data, the researcher gave the students a questionnaire and a reading test. The questionnaire used for this research was PLSPQ (Perceptual Learning Style Preference Questionnaire) by Reid (1987) to decide the students' learning style. After knowing their learning style, the students were asked to do the reading test provided by the researcher. Then, the reading score would show the achievement of students by also considering the highest and lowest aspect for each learning style.

\section{Data analysis}

After collecting the data, it was analyzed. The non subjects of research were asked to do the try out test by the researcher to find out the reliability and validity of the test. While the subjects of research did the questionnaire and the researcher tabulated the result. After that, the students were asked to do the reding test. The data were analyzed by using One Way Anova in SPSS 
17.0 for Windows. The researcher also analyzed using MANOVA (Multivariate Analysis of Varience) in order to determined the highest and lowest aspect of reading that were acquired from each VAK learning style.

\section{RESULTS ${ }^{2)}$ AND DISCUSSIONS}

\section{The Result of Try out Test}

After conducting the try out test, the researcher obtained the result. The researcher measured the validity of the test using Pearson Product Moment, and the result is shown below:

Table 1. Validity of Try Out Test

\begin{tabular}{|lll|}
\hline Question & Sig (2-tailed) & Decision \\
\hline Q1 & 0.000 & Valid \\
\hline Q2 & 0.000 & Valid \\
\hline Q3 & 0.012 & Valid \\
\hline Q4 & 0.002 & Valid \\
\hline Q5 & 0.006 & Valid \\
\hline Q6 & 0.001 & Valid \\
\hline Q7 & 0.000 & Valid \\
\hline Q8 & 0.316 & Invalid \\
\hline Q9 & 0.000 & Valid \\
\hline Q10 & 0.006 & Valid \\
\hline Q11 & 0.002 & Valid \\
\hline Q12 & 0.001 & Valid \\
\hline Q13 & 0.692 & Invalid \\
\hline Q14 & 0.823 & Invalid \\
\hline Q15 & 0.000 & Valid \\
\hline Q16 & 0.000 & Valid \\
\hline Q17 & 0.012 & Valid \\
\hline Q18 & 0.012 & Valid \\
\hline Q19 & 0.002 & Valid \\
\hline Q20 & 0.006 & Valid \\
\hline Q21 & 0.001 & Valid \\
\hline Q22 & 0.000 & Valid \\
\hline Q23 & 0.000 & Valid \\
\hline Q24 & 0.001 & Valid \\
\hline Q25 & 0.074 & Invalid \\
\hline Q26 & 0.002 & Valid \\
\hline Q27 & 0.000 & Valid \\
\hline Q28 & 0.006 & Valid \\
\hline Q29 & 0.012 & Valid \\
\hline Q30 & 0.001 & Valid \\
\hline Q31 & 0.000 & Invalid \\
\hline Q32 & 0.823 & Valid \\
\hline Q33 & 0.000 & Valid \\
\hline Q34 & 0.001 & \\
\hline Q35 & 0.000 & \\
\hline & & \\
\hline
\end{tabular}


Based on the Table 1, the questions number $8,13,14,25,32$ were the invalid items and must be dropped. So, there were 30 question items properly used.

Table 2. Reliability of Try Out Test

\begin{tabular}{|c|c|c|c|}
\hline \multicolumn{4}{|l|}{ Reliability Statistics } \\
\hline Cronbach's Alpha & Part 1 & Value & .850 \\
\hline & & $\mathrm{N}$ of Items & $15^{\mathrm{a}}$ \\
\hline & Part 2 & Value & .858 \\
\hline & & $\mathrm{N}$ of Items & $15^{\mathrm{b}}$ \\
\hline & & Total $\mathrm{N}$ of Items & 30 \\
\hline & & Correlation Between Forms & .905 \\
\hline \multirow[t]{3}{*}{ Spearman-Brown Coefficient } & & Equal Length & .950 \\
\hline & & Unequal Length & .950 \\
\hline & & Guttman Split-Half Coefficient & .950 \\
\hline
\end{tabular}

For the reliability of the try out test, the researcher measured using Split-Half method. Based on the Table 2, from 30 valid items, the reliability was 0.950 which meant the test was reliable and could be used to measure the students' reading comprehension achievement.

\section{The Result of Questionnaire}

After conducting the questionnaire, the researcher measured the validity using Pearson Correlation in SPSS 17.0 for windows, and the result is shown below:

Table 3. Validity of Questionnaire

\begin{tabular}{|ccc|}
\hline Statement & Sig (2-tailed) & Decision \\
\hline S1 & 0.000 & Valid \\
\hline S2 & 0.000 & Valid \\
\hline S3 & 0.001 & Valid \\
\hline S4 & 0.000 & Valid \\
\hline S5 & 0.000 & Valid \\
\hline S6 & 0.001 & Valid \\
\hline S7 & 0.004 & Valid \\
\hline S8 & 0.001 & Valid \\
\hline S9 & 0.000 & Valid \\
\hline S10 & 0.001 & Valid \\
\hline S11 & 0.000 & Valid \\
\hline S12 & 0.000 & Valid \\
\hline S13 & 0.001 & Valid \\
\hline S14 & 0.000 & Valid \\
\hline S15 & 0.000 & Valid \\
\hline
\end{tabular}

Based on the Table 3, it concluded that the questionnaire was valid from the first statement to the fifteenth statement with the significance 2 tailed $<0.05$. 
Table 4. Reliability of Questionnaire

Reliability Statistics

\begin{tabular}{|rr|}
\hline Cronbach's Alpha & N of Items \\
\hline .803 & 15 \\
\hline
\end{tabular}

In order to make sure that the questionnaire was reliable, the researcher analyzed it by using Cronbach Alpha in SPSS 17.0 for Windows. Then, the result of the reliability was $0.803(\alpha>$ 0.5). It meant that the reliability of the questionnaire was high based on Cronbach's scale.

After analyzing the data, the researcher obtained the result of the questionnaire which was presented below:

Figure 1. Students' Learning Style

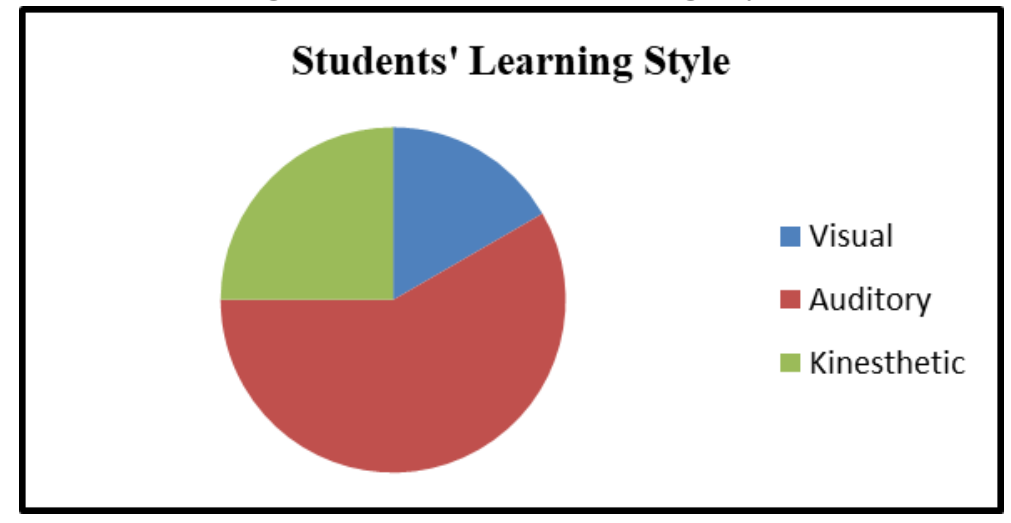

Based on the Figure 1, the result of the questionnaire showed 6 students were classified as visual students, 15 students were classified as the auditory one, and 9 students were classified as kinesthetic students.

The Reading Comprehension Achievement among Visual, Auditory, and Kinesthetic Students

After tabulating the data, the researcher analyzed it using One Way Anova with the result below:

Table 5. One Way Anova (Descriptives)

Descriptives

reading test score

\begin{tabular}{|c|c|c|c|c|c|c|c|c|}
\hline & \multirow{2}{*}{$\mathrm{N}$} & \multirow{2}{*}{ Mean } & \multirow{2}{*}{ Std. Deviation } & \multirow{2}{*}{ Std. Error } & \multicolumn{2}{|c|}{ 95\% Confidence Interval for Mean } & \multirow{2}{*}{ Minimum } & \multirow{2}{*}{ Maximum } \\
\hline & & & & & Lower Bound & Upper Bound & & \\
\hline visual & 6 & 70.67 & 7.737 & 3.159 & 62.55 & 78.79 & 61 & 81 \\
\hline auditory & 15 & 75.80 & 9.435 & 2.436 & 70.57 & 81.03 & 61 & 97 \\
\hline kinesthetic & 9 & 69.11 & 13.421 & 4.474 & 58.80 & 79.43 & 48 & 81 \\
\hline Total & 30 & 72.77 & 10.621 & 1.939 & 68.80 & 76.73 & 48 & 97 \\
\hline
\end{tabular}

From the Table 5, the data showed that the mean score of all students was 72.77 with the minimum and maximum score were 48 and 97 . The auditory learning style obtained the highest 
mean score with 75.80 , while the visual learning style obtained 70.67 and the kinesthetic learning style was 69.11 .

Table 6. Hypothesis Testing

ANOVA

reading test score

\begin{tabular}{|lrrrrr|}
\hline & Sum of Squares & Df & Mean Square & F & \multicolumn{1}{c|}{ Sig. } \\
\hline Between Groups & 284.744 & 2 & 142.372 & 1.287 & .292 \\
Within Groups & 2986.622 & 27 & 110.616 & & \\
Total & 3271.367 & 29 & & & \\
\hline
\end{tabular}

For determining the hypothesis testing, the researcher used One Way Anova. As the Table 6 showed, the $F$ value was 1.287 with the significance .292 . The researcher also calculated the $F$ table was 0.158 . It showed that $\mathrm{F}$ value $>\mathrm{F}$ table which concluded that $\mathrm{H}_{1}$ was accepted and $\mathrm{H}_{0}$ was declined.

\section{The VAK Students' Achievement in Five Aspects of Reading Comprehension}

In this part, the researcher analyzed the achievement of the students by considering the aspect of reading comprehension. The researcher used Multivariate Analysis of Variance (MANOVA) in SPSS 17.0. The result is shown below:

Tabel 7. Multivariate Analysis of Variance (MANOVA)

Descriptive Statistics

\begin{tabular}{|cccccc|}
\hline & learning style & Mean & Std. Deviation & $\mathrm{N}$ & Sig. \\
\hline \multirow{5}{*}{ main idea } & Visual & 3.00 & 1.095 & 6 & .000 \\
& auditory & 3.73 & 1.438 & 15 & .000 \\
& kinesthetic & 3.78 & 1.202 & 9 & .000 \\
& Total & 3.60 & 1.303 & 30 & .000 \\
\hline \multirow{5}{*}{ specific information } & Visual & 3.33 & 1.211 & 6 & .000 \\
& auditory & 4.13 & .915 & 15 & .000 \\
& kinesthetic & 4.00 & 1.118 & 9 & .000 \\
& Total & 3.93 & 1.048 & 30 & .000 \\
\hline \multirow{5}{*}{ Reference } & Visual & 4.67 & .516 & 6 & .000 \\
& Auditory & 5.33 & .724 & 15 & .000 \\
& Kinesthetic & 4.56 & 1.590 & 9 & .000 \\
& Total & 4.97 & 1.066 & 30 & .000 \\
\hline \multirow{5}{*}{ Inference } & Visual & 4.50 & 1.049 & 6 & .000 \\
& Auditory & 4.33 & .617 & 15 & .000 \\
& Kinesthetic & 3.67 & 1.118 & 9 & .000 \\
& Total & 4.17 & .913 & 30 & .000 \\
\hline \multirow{6}{*}{ Vocabulary } & Visual & 5.00 & .000 & 6 & .000 \\
& Auditory & 5.13 & .743 & 15 & .000 \\
& Kinesthetic & 4.44 & 1.130 & 9 & .000 \\
& Total & 4.90 & .845 & 30 & .000 \\
\hline
\end{tabular}

According to table 7, the lowest aspect achieved by visual students was finding main idea (3.00) and the highest aspect was determining vocabulary (5.00). However, the lowest aspect of the 
auditory students was finding main idea (3.73) and the highest aspect was determining reference (5.33). The lowest aspect of the kinesthetic group was making inference (3.67) and the highest aspect was determining reference (4.56).

\section{Discussion of the Difference among Students' VAK Learning Style in Reading Comprehension Achievement}

Based on the result, the visual, auditory, and kinesthetic students of X IPA 6 had significant difference in reading comprehension achievement. This finding resonates with Rachma et al., (2015) and the study of Febrianti (2014) which reported this study revealed that the learning style was significantly affected by their reading comprehension achievement. It seemed that there was interdependence between two kinds of style either auditory or visual that helped students to gain better reading comprehension. Frankly speaking, the learning styles of English students who became participants of this study whether they are visually oriented or auditory oriented were reflected in their reading achievement.

Furthermore, Caldwell et al., (1996) studied the relationship between learning styles using Dunns' inventory and reading achievement students. The result showed significant differences between high achieving readers and low achieving readers. This was supported by Foley (1999) who also found evidence that supports the effect of learning style preference on reading achievement. The results showed statistically significant differences between low and high performing students in their reported learning style preferences.

Based on the finding of this research, the auditory students obtained the highest mean score of reading test among others. As proposed by Joycey (2006), reading and listening are receptive skills. The differences between those skills are reading is a written text, while the other one is oral text but the processes are similar. There are substantial correlations among these language achievements. So when students have good skill in listening, they will have a good skill in reading. Therefore, in this research, the auditory students reached the highest scores. It would be hard to understand why the auditory students achieved the highest score in reading. To simplify, students which had a good skill in listening, they would be good in reading achievement.

To support this finding, Pollack and Miller (2005) said that auditory learners remember the detail of texts and they also have strong language skills. It also could be caused by their good ability in reading text loudly and understanding the text better through what they have read, speak for themselves, and memorize it. So the auditory students are able to memorize faster by reading text loudly and understanding it easily.

Another theory, Ellis (1985) argued that language learners have differences of personality, learning style, motivation, aptitude or even their ability which positively or negatively affect their reading achievement (Brown \& Palinscar, 1984; Hannon \& Daneman, 2007). In this research, results showed that students with high auditory learning styles achieved the highest score and may understand the texts as they were focused by oral reading protocols. Students with an auditory preference prize sound and can make decisions based on what they have heard or read.

According to the result of this research, it was also found that the second learning style which was good in reading achievement was visual learning style. According to Poon (1993), students 
with a visual preference see the world by constructing or remembering mental images. It may make visual learning style easier for the students, more attractive, and less power required.

And last, the lowest score of reading test was kinesthetic learning style. Whether these students had a good habit of always remembering and making notes while they read, they also used their efficient reading strategies which also helped them to stay focused. This finding supported by Honey \& Mumford (1999:17), kinesthetic learning style is a learning style in which learning takes place by the student carrying out a physical activity, rather than listening to a lecture or watching a demonstration.

\section{Discussion of the Highest and the Lowest Aspects of each VAK Learning Style}

In these findings, the highest reading aspect of visual students was finding vocabulary and the lowest aspect was finding main idea. Furthermore, most of the main idea question items were considered as difficult questions for the students. This was caused by the students having been expecting to find the idea quickly without adjusting the options. It was in line with Nuttal (1982), readers' understanding in main ideas depends not only on the information presented in the text but also on their prior knowledge and expectations, in fact no main idea exists in a text.

However, in auditory students, the highest aspect was determining reference and the lowest aspect was finding main idea. This happened because the students were too lazy to read long sentences and lack an understanding of sentence patterns to identify the main idea. It is in line with Dwiarti (2005) who says that the length of the sentence and poor strategy are problems that students are facing in identifying the main idea. Therefore, this might be the reason why identifying the main idea became the lowest achievement.

Last, in kinesthetic students, the highest aspect was determining reference and the lowest aspect was determining inference. Making inference was quite difficult for students to answer because the students needed to look and use context clues in the passage since the answer was not directly stated in order the students could answer the inference question correctly. This is in line with Graesser and Wiemer (2001) say that inference is the output of the interaction between the reader's knowledge and the information which indirectly provided in the text.

From the explanation above, it concluded that finding the main idea was the most difficult aspect for the visual and auditory students because not only the information presented in the text but also on their knowledge and expectations. Besides, making inference was the lowest gain for kinesthetic students because it was not directly stated within the passage. However, the determining reference was the highest gain for the auditory and kinesthetic students because it used to avoid unnecessary repetition of words or phrases and they know how to solve it. In addition, determining vocabulary was the highest gain for visual students because they understand what they are reading with knowing words mean.

\section{CONCLUSIONS AND SUGGESTIONS}

\section{Conclusions}

The reading achievement of visual, auditory, and kinesthetic students in X IPA 6 of SMAN 3

Bandar Lampung are statistically significantly different. In comparing the visual, auditory, and kinesthetic students, the results showed that auditory students obtained the highest score in 
reading comprehension achievement among the other styles. This happened because students who had a good skill in listening, they would be good in reading achievement. Although reading usually could be handled by visual students, in fact, auditory students were better at reading comprehension achievement. They used to understand easily by reading and speaking the text by themselves. As a result, auditory students did a reading test easily and achieved the highest result among the other students. Based on the aspects of reading, the highest gain of visual students was vocabulary and the lowest gain was the main idea. The highest gain of auditory students was reference and the lowest gain was main idea. However, the aspect with highest gain of kinesthetic was reference and the lowest gain was inference.

\section{Suggestions}

For the English teacher, it is suggested to focusly increase the aspects of reading that had the lowest gain of students, for example, finding main ideas and making inferences. The teacher also has to consider the learning style of each student and combine the method of teaching. So the students could achieve better in a class. Educational tools that support the different learning styles of students should be provided to support the students' reading achievement particularly the stability gained of the aspects. Besides, for further research, it is suggested to conduct this research in others schools to enlarge the research objects. In addition, adding the other variable influenced the reading achievement such as the internal and external factors.

\section{REFERENCES}

\section{Book}

Anderson, R. D., Hiebert, E., Scott, A, J., \& Wilkinson, I. A. (1985). The report of the comission on reading. Washington, DC: The National Academic of Education.

Bidabadi, F. S., \& Yamat, H. (2010). Learning style preferences by Iranian EFL freshman university students (p. 219-226). Procedia - Social and Behavioral Sciences.

Bricheno, P., \& Younger, M. (September 2004). Some unexpected result of a learning styles intervention. Cambridge: BERA Conference.

Brown, A. L., \& Palincsar, A.S. (1984). Reciprocal teaching of comprehension-fostering and comprehension-monitoring activities. Cognition and Instruction, 1(2), 117-175.

Caldwell, G. P., \& Ginthier, D. W. (1996). Differences in learning style of low socioeconomic status for low and high achievers. Education, 392.

Dunn, Rita, \& Dunn, Kenneth. (1993). Teaching secondary students through their individual learning styles: Practical approaches for grades 7-12. Boston: Allyn \& Bacon.

Dwiarti, E. 2005. An analysis of students' problems in finding the main idea of the text at second year of SMU Kosgoro Sekampung, East Lampung. A Script, FKIP, University of Lampung.

Ellis, R. (1985). Understanding second language acquisition. Oxford: OUP.

Febrianti, S. (2014). Students' reading comprehension based on their learning styles. Jakarta: Syarif Hidayatullah State Islamic University. 
Fithrotunnisa, E. D. (2015). The comparative analysis of students' learning style on their achievement in reading skill. Jakarta: Syarif Hidayatullah State Islamic University.

Foley, I. (1999). Teacher learning style preferences, student learning style preferences and student reading achievement (Doctoral dissertation). Available from ProQuest Dissertation and theses databases. (UMI No. 9929271).

Graesser, A. C., Wiemer-Hastings, P., \& Wiemer-Hastings, K. (2001). Constructing inferences and relations during text comprehension. In T. Sanders, J. Schilperoord, \& W. Spooren (Eds.), Human Cognitive Processing, Vol. 8. Text representation: Linguistic and psycholinguistic aspects (p. 249-271). John Benjamins Publishing Company.

Hannon, B., \& Daneman, M. (2007). Prospective memory: The Relative Effects of Encoding, Retrieval, and the Match between Encoding and Retrieval Memory. doi:10.1080/09658210701407281, 15, 572-604.

Honey, P., \& Mumford, A. (1999). Manual of learning styles. London: P. Honey.

Joycey, E. (2006). Reading comprehension: An interactive process. Available on:http//ilciral.com/737/1017/-21k (Accessed on October 27, 2020)

Mulalic, A., Mohd Shah, P., \& Ahmad, F. (2009). Preceptual learning styles of ESL students. European Journal of Social Sciences, 101-113.

Nuttal, C. (1982). Teaching reading skills in a foreign language. London: Heinemann Educational Books.

Oakhill, J. (1993). Children's difficulties in reading comprehension. Educational Psychology Review, 223-237.

Pollack, M. S., \& Miller, D. S. (2005). Teachers, School, and Societies. New York: Mc Graw Hill.

Poon, J. T. (1993). Learning styles in training: teaching learners the way they learn. Industrial and Commercial Training, 19.

Rachma, N., Sutarsyah, \& Rizal, H. (2015). The effect of learning style on students' reading comprehension achievement. Life Science Journal, 2236.

Reid, J. M. (1987). The learning style preferences of ESL students. TESOL Quarterly. 